KONSTRUKTIVISME, Vol. 10, No. 1, Januari 2018

p-ISSN: 1979-9438; e-ISSN: 2442-2355

FKIP Universitas Islam Balitar, Blitar

Http://konstruktivisme.unisbablitar.ejournal.web.id; Email: konunisba@gmail.com

\title{
PERANAN MANAJEMEN PERSONALIA DALAM MENINGKATKAN MUTU PENDIDIDIKAN DI MI WALISONGO SELOREJO BLITAR
}

\author{
Muhammad lqbal Baihaqi \\ Prodi PGSD FKIP Universitas Islam Balitar Blitar \\ Jl. Majapahit No. 04 Blitar \\ E-mail : iqbal baihaqi123@yahoo.co.id
}

\section{ABSTRAK:}

Tujuan dari penelitian saya adalah untuk mengetahui tentang bagaimana pelaksanaan manajemen personalia di MI Walisongo, untuk mengetahui tentang peranan manajemen personalia dalam meningkatkan mutu pendidikan di Ml Walisongo, dan untuk mengetahui apa faktor penghambat dan pendukung pelaksanaan manajemen personalia di MI Walisongo. Penelitian yang penulis lakukan termasuk kedalam penelitian deskriptif kualitatif. Adapun metode pengumpulan datanya penulis menggunakan metode observasi, wawancara, dan dokumentasi. Sedangkan untuk analisanya penulis menggunakan teknik analisis deskriptif kualitatif. Hasil dari penelitian yang saya lakukan ini bahwasannya manajemen personalia yang dikelola dengan professional sebagai alternative jalan keluar untuk meningkatkan mutu pendidikan di madrasah. Manajemen personalia ini dapat digunakan sebagai motor penggerak organisasi pendidikan sehingga madrasah dapat mengatasi dari pada keterbatasan sarana dan prasarana yang sering terjadi pada sekolah dan tetap mengikuti perkembangan jaman dan tentu saja perkembangan dunia pendidikan.

Kata Kunci: Manajemen Personalia, Mutu Pendidikan

\section{ABSTRACT:}

The aims of this research were to know how the implementation of personnel management at MI Walisongo, to find out the role of personnel management in improving the quality of education at MI 
Walisongo, and to find out what are the inhibiting and supporting factors in the implementation of personnel management at $\mathrm{Ml}$ Walisongo. The research was descriptive qualitative. The data collection method used observation, interview, and documentation method. While to analyse used descriptive qualitative analysis techniques. The result of the research showed that personnel management which managed with professionals as an alternative way to improve the quality of education in school. A personnel management can used as activator of educational organization so that the school can handle the limited facilities and infrastructure which often happens in school and following of the era development and the world of education development.

Keywords: Personnel Management, Quality of Education.

\section{PENDAHULUAN}

Mutu pendidikan merupakan salah satu masalah pendidikan yang kompleks. Kompleksitas dari permasalahan ini disebabkan oleh banyaknya variabel yang saling mempengaruhi, salah satunya adalah manajemen dan pengelolaan yang ada pada lembaga tersebut. Dalam rangka meningkatkan kualitas lembaga pendidikan Islam agar dapat menarik minat masyarakat untuk menyekolahkan putra-putri mereka ke lembaga pendidikan Islam maka sistem lama harus secepatnya dirubah dan melakukan inovasi-inovasi baru kearah itu.

Manajemen merupakan komponen integral dan tidak dapat dipisahkan dari proses pendidikan secara keseluruhan. Tanpa manajemen yang baik, tujuan pendidikan tidak dapat diwujudkan secara optimal efektif dan efisien. Penerapan manajemen sekolah secara menyeluruh memerlukan perubahan mendasar pada aspek-aspek yang menyangkut keuangan, ketenagaan, kelas kurikulum, sarana dan prasarana serta partisipasi dari masyarakat dan lain-lain. Manajemen yang diterapkan di sekolah salah satunya adalah manajemen personalia, peranan manajemen personalia dalam meningkatkan mutu Madrasah sangat diperlukan. Mutu dan performa suatu Madrasah tertentu tergantung bagaimana kualitas personal dalam mengelola dan mengembangkan sumber-sumber yang ada di Madrasah tersebut.

Hasil observasi yang dilakukan di MI Walisongo yaitu Madrasah Ibtidaiyah Walisongo ini merupakan Madrasah yang masih dalam tahap 
pengembangan.. Dalam perjalanannya, Madrasah ini telah berhasil membangun beberapa lokal gedung, dan dapat meningkatkan jumlah siswasiswinya. Padahal lingkungan disekitar Madrasah tersebut dapat dikatakan masyarakat ekonomi menengah kebawah yang belum begitu manyadari arti pendidikan bagi putra-putri mereka. Mereka lebih tertarik kepada sekolah umum yang sudah mempunyai predikat bagus dan mempunyai nama di masyarakat.

Penelitian ini memiliki tujuan: 1) Pelaksanaan manajemen personalia di MI Walisongo Kabupaten Blitar. 2) Peranan manajemen personalia dalam meningkatkan mutu pendidikan di MI Walisongo Kabupaten Blitar. 3) Faktor penghambat dan pendukung manajemen personalia dalam meningkatkan mutu pendidikan di MI Walisongo Kabupaten Blitar.

\section{METODE}

\section{Pendekatan dan jenis Penelitian}

Penelitian ini menggunakan pendekatan kualitatif. Penelitian kualitatif dapat dipergunakan untuk menemukan dan memahami apa yang tersembunyi dibalik fenomena yang terjadi. Penelitian kualitatif ini juga diharapkan mampu memberikan penjelasan secara terperinci tentang fenomena yang sulit disampaikan dalam metode kuantitatif. Adapun jenis penelitian yang saya lakukan ini adalah penelitian jenis studi kasus.

\section{Lokasi Penelitian}

Penelitian ini bertujuan untuk mendapatkan gambaran dan informasi yang lebih jelas dan lengkap mengenai peranan manajemen personalia (sebagai bagian dari manajemen pendidikan) dalam meningkatkan mutu pendidikan di MI Walisongo Selorejo-Blitar. Pemilihan lokasi penelitian ini didasarkan pada pertimbangan-pertimbangan tertentu agar jalannya penelitian berlangsung dengan baik. Lokasi ini dipilih oleh peneliti karena mudah bagi peneliti untuk melakukan penelitian dan observasi. Oleh karena itu, peneliti memilih MI walisongo sebagai obyek penelitian

\section{Waktu dan Tempat Penelitian}

Waktu dilaksanakannya penelitian ini adalah tahun pelajaran 2016/2017. pada bulan Februari 2017. Tempat berlangsungnya penelitian ini adalah di MI Walisongo Selorejo Blitar 


\section{Subyek Penelitian}

Subyek penelitian ini adalah seluruh dewan guru dan staf di MI Walisongo Selorejo Blitar.

\section{Sumber Data}

Sumber data dalam penelitian kualitatif ada dua macam yaitu sumber data primer dan sumber data skunder.

a. Sumber data primer adalah adalah Kepala Sekolah,wakil serta seluruh guru dan staf administratif.

b. Sedangkan sumber data skunder dari penelitian ini adalah sumber data yang tidak langsung, misalnya lewat sumber lain atau dokumen. Dan bersifat tertulis dari lembaga.

\section{Teknik Pengumpulan Data}

peneliti dalam hal ini menggunakan metode sebagai berikut :

a. Metode Observasi. Metode ini merupakan suatu usaha sadar untuk mengumpulkan data yang dilakukan secara sistematis dengan prosedur yang standar

b. Metode Wawancara. adalah proses memperoleh keterangan untuk tujuan penelitian dengan menggunakan model Tanya jawab sambil bertatap muka antara si penanya atau pewawancara terhadap responden dengan menggunakan alat atau panduan wawancara

c. Metode Dokumentasi.Metode ini berdasarkan dokumen yang ada untuk mengetahui tentang latar belakang obyek penelitian. Latar belakang obyek penelitian ini meliputi sejarah singkat berdiri dan berkembangnya MI Walisongo kabupaten Blitar serta kondisi guru dan karyawan MI Walisongo kabupaten Blitar.

\section{Teknik Analisis Data}

Peneliti dalam hal ini menganalisis data hasil penelitian dengan deskriptif-kualitatif yang merupakan suatu teknik yang menggambarkan, menguaraikan dan menginterpretasikan data-data yang terkumpul dengan memberi perhatian dan merekam sebanyak mungkin aspek situasi yang diteliti. Teknik analisis data ini depergunakan untuk menyusun laporan hasil penelitian yang telah penulis lakukan di MI Walisongo 


\section{Pengecekan Keabsahan Data}

Adapun teknik pemeriksaan data yang ada dalam penelitian ini menggunakan kriteria derajat kepercayaan dengan pemeriksaan datanya menggunakan metode trianggulasi. Menurut Lexy $\mathrm{J}$ Moleong triangulasi adalah teknik pemeriksaan keabsahan data yang memanfaatkan sesuatu yang lain diluar data itu untuk kepentingan pengecekan dan sebagai pembanding terhadap data itu. Teknik triangulasi yang paling banyak digunakan ialah pemeriksaan melalui sumber lain. Penelitian ini termasuk ke dalam kriteria derajat kepercayaan (kredibilitas). Dengan teknik analisis data sesuai dengan teknik pengecekan keabsahan data yang sudah ditentukan. Penelitian ini difokuskan pada kepercayaan kinerja personil sekolah dalam meningkatkan mutu pendidikan

\section{Tahap Penelitian}

a. Tahap Pra Lapangan

1) Menyusun rancangan penelitian.

2) Memilih tempat yang akan dijadikan objek penelitian dengan pertimbangan.

3) Mengurus perijinan secara formal.

4) Melakukan penjajahan lapangan untuk menyesuaikan dengan $\mathrm{Ml}$ selaku obyek penelitian.

5) Menyiapkan perlengkapan penelitian.

b. Tahap Pekerjaan Lapangan

1) Mengadakan observasi secara langsung.

2) Memasuki lapangan tempat objek penelitian,kemudian

3) Mengumpulkan data dari berbagai sumber tertulis dan dengan mengamati berbagai fenomena yang ada pada obyek penelitian kemudian wawancara dengan berbagai pihak yang terlibat dalam fokus penelitian ini.

c. Penyusunan laporan penelitian berdasarkan hasil yang diperoleh 


\section{HASIL DAN BAHASAN}

\section{Hasil}

1. Latar Belakang Obyek Penelitian

a) Profil Madrasah

Nama Madrasah

: MI Walisongo Selorejo

Nama Yayasan

: LP Ma'arif NU

Alamat

: Jl Tugu ljen No. 03 Selorejo Blitar

Provinsi

: Jawa Timur

b) Visi Misi Sekolah

Visi: Unggul dalam prestasi berwawasan kebangsaan dalam iman dan taqwa

Misi: peningkatan kwalitas pembelajaran dan keprofesionalisme, berpacu untuk meraih prestasi akademik dan non akademik, penerapan dan pemahaman realita kehidupan

c) Sarana prasarana

Ruang kelas, Lapangan Olah raga,Dapur,Perpustakaan, Mushola

d) Tenaga Pendidik

1. Siti hajar munawaroh, S.Pdl

2. Juwarni S.Pd

3. Nurul hidayati S.Pd

4. Ritnawati S.Pd

5. Nenin milu S.Pd

6. Elly kristinawati S.Pd

7. Siti mubatariyah S.Pd

8. Nanik setyowati S.Pd

9. Subur hardiantoko S.Pd

10. Friska Violita S.Pd

11. Dianika Wulandari S.Pd

12. Nira Eka safitri S.Pd

13. M Khoiru Rofiqin S.PdI

14. Muhammad Mukhtar S.Pdl

2. Peranan Manajemen Personalia Dalam Meningkatkan Mutu Pendidikan di MI Walisongo Selorejo - Blitar 
Manajemen pendidikan tidak bisa terlepas dari pelaksana (personal) manajemen. Apabila pelaksana (personal) manajemen tersebut mampu melaksanakan segala proses yang ada dalam manajemen dengan baik, maka semua komponen yang ada di lembaga tersebut akan berjalan sesuai dengan apa yang direncanakan dan ditargetkan. Dalam hai ini kepala madrasah dan seluruh komponen yang ada di Madrasah dituntut memiliki visi, tanggungjawab, wawasan, dan ketrampilan megelola dengan sebaikbaiknya.

Peningkatan kualitas mutu suatu pendidikan bukanlah tugas yang ringan karena tidak hanya berkaitan dengan permasalahan teknis akan tetapi mencakup berbagai persoalan yang sangat rumit dan kompleks, baik yang mencakup perencanaan, pendanaan, efesiensi dan efektifitas penyelenggaraan sekolah. Penigkatan kualitas pendidikan juga harus di imbangi manajemen yang baik. Sayangnya selama ini aspek manajemen pendidikan pada berbagai tingkat dan satuan pendidikan khususnya di madrasah belum mendapat perhatian yang serius sehingga seluruh komponen sistem pendidikan kurang berfungsi dengan baik. Lemahnya managerial juga memberikan dampak terhadap efisiensi internal pendidikan.

Personal sekolah seperti guru dan staf karyawan tentu saja membutuhkan motivasi untuk meningkatkan kinerjanya. Adapun usaha untuk menigkatkan mutu kinerja guru dan staf karyawan seperti yang dikemukakan oleh Kepala Sekolah MI Walisongo Selorejo-Blitar ialah melalui kegiatan kelompok kerja guru (KKG) untuk para guru, dan untuk mendapatkan informasi mengenai mutu pendidikan kami selalu koordinasi dengan kepala-kepala madrasah se kabupaten Blitar melalui(K3MI),setiap bulan atau bahkan kebutuhan (incidenta). Selain itu juga tetap berkordinasi dengan lembaga terkait yaitu kemenag serta LP MA'ARIF

Dengan meningkatkan kinerja personil sekolah secara berkesinambungan dan evaluasi disetiap jenis kegiatan personal kualitas kinerja personal akan teridentifikasi dengan baik untuk memonitor kualitas atau mutu pendidikan di madrasah ini. Mutu pendidikan pun juga harus terus ditingkatkan dari waktu kewaktu begitu juga mutu pendidikan yang ada di MI Walisongo Selorejo-Blitar ini.

peranan manajemen personalia dalam meningkatkan mutu pendidikan sebagai kunci utama keberhasilan pencapaian tujuan pendidikan. Personalia dituntut untuk mengetahui potensi yang ada di 
sekitar mereka dan memanfaatkaannya dengan efektif dan efisien untuk menigkatkan mutu pendidikan di madrasah.

Personil sekolah merupakan pelaku atau subyek pengembang mutu pendidikan ditengah perkembangan yang sangat pesat tiap waktunya. Personil sekolah akan selalu dihadapkan pada kendala dan masalahmasalah yang terus terjadi. Setiap masalah perlu sesegera mungkin dicarikan jalan keluar dan pemecahannya agar tidak berlarut-larut. Untuk kepentingan tersebut perlu adanya kegiatan pertemuan baik dengan unsure sekolah atau luar sekolah.

Peningkatan pengetahuan dan kemampuan profesional sering harus dilaksanakan untuk mengatasi masalah yang dihadapi. Personil sekolah mengemban tugas untuk menjadi fasilitator bagi siswa untuk hidup bermasyarakat dan mengembangkan dirinya kelak.

Oleh karena itu untuk melaksanakan tugas tersebut dengan baik maka personil sekolah harus memiliki kepribadian tahan uji dalam meningkatkan mutu pendidikan. Selain itu personal sekolah juga diharapkan mempunyai hubungan yang harmonis antara personal agar setiap program sekecil apapun untuk meningkatkan mutu pendidikan dapat terealisasikan dengan maksimal.

\section{Faktor Penghambat Dan Pendukung Manajemen Personalia Dalam Meningkatkan Mutu Pendidikan Di MI Walisongo Selorejo - Blitar}

Faktor pendukung dalam meningkatkan mutu pendidikan adalah tingkat kekompakan dari semua komponen yang ada di madrasah baik dari kepala,satf, dewan guru juga siswa. dengan tingkat kekompakan yang tinggi akan membuat sekolah itu menjadi lebih baik, selain itu kerjasama dengan komite/ wali murid dengan mengadakan rapat dengan wali murid juga bisa dijadikan sebagai salah satu media untuk meningkatkan mutu lembaga.

Adapun faktor penghambat yaitu jumlah tenaga kependidikan masih terbatas, sarana prasarana yang belum memadai, hambatan lain yang dihadapi MI Walisongo adalah Dana yang minim dengan kondisi sosial ekonomi peserta didik yang rendah sehingga pihak madrasah tidak bisa membebankan biaya pendidikan yang besar kepada siswa. Akan tetapi dengan loyalitas tinggi, komitmen, dan team-work yang kompak serta komunikasi yang terbangun dengan baik di semua lini serta semangat 
perjuangan yang tinggi madrasah ini akan mampu bertahan dan bersaing dengan madrasah lain yang ada di Kabupaten Blitar.

\section{PEMBAHASAN}

\section{Pelaksanaan Manajemen Personalia di MI Walisongo Kabupaten Blitar}

a) Perencanaan Pegawai.

Perencanaan atau planning adalah kegiatan awal dalam sebuah pekerjaan dalam bentuk memikirkan hal-hal yang terkait dengan pekerjaan itu agar mendapat hasil yang optimal.

Perencanaan itu sendiri juga harus disesuaikan dengan kemampuan finansial yang memadai Bagi pegawai yang masa kerjanya relatif lama itu yang menjadi prioritas, dengan pertimbangan masa kerja yang cukup lama, mereka akan profesional dan menguasai terhadap bidang tugas yang diemban. Namun demikian sebelumnya harus diadakan evaluasi, jadi masa kerja yang cukup lama bukan menjadi prioritas utama, akan tetapi tergantung pada profesionalitas dan kualitas personal

b) Pengadaan Personalia.

Pengadaan pegawai merupakan kegiatan untuk memenuhi kebutuhan pegawai pada suatu lembaga, baik jumlah maupun kualitasnya. Untuk mendapatkan pegawai yang sesuai dengan kebutuhan dilakukan kegiatan rekruitmen, yaitu usaha untuk mencari dan mendapatkan calon-calon pegawai yang sesuai syarat sebanyak mungkin, untuk kemudian dipilih calon terbaik yang cakap.

Untuk kepentingan tersebut perlu dilakukan seleksi, melalui ujian lisan, tulisan dan praktek. namun adakalanya, pada intern atau dalam organisasi, pegawai dapat didatangkan dari intern organisasi saja, apakah melalui promosi atau mutasi.

\section{c) Pembinaan Dan Pengembangan}

Pembinaan dan pengembangan pegawai merupakan fungsi pengelolaan personil yang mutlak perlu, untuk memperbaiki, menjaga dan meningkatkan kinerja pegawai. kegiatan ini dapat dilakukan dengan cara on the job training dan in service training. Kegiatan pembinaan dan pengembangan ini tidak hanya menyangkut aspek kemampuan, tetapi juga menyangkut karier pegawai. 
lain :

Peningkatan mutu kinerja personal sekolah di MI Walisongo antara

1) Mengefektifkan kegiatan musyawarah guru mata pelajaran (KKG) untuk bidang studi skupnya adalah sekabupaten.

2) KKKN atau K3N (kelompok kerja kepala sekolah) pelaksanaan satu bulan sekali pada minggu pertama.

3) Seminar,diklat, dan work shop untuk mengikuti perkembangan terbaru dalam dunia pendidikan.

\section{e) Promosi Dan Mutasi}

Setelah diperoleh dan ditentukan calon pegawai yang akan diterima, kegiatan selanjutnya adalah mengusahakan supaya calon pegawai tersebut menjadi anggota organisasi yang sah sehingga menjadi mempunyai hak dan kewajiban sebagai anggota organisasi atau lembaga

Adapun pertimbangan-pertimbangan promosi pegawai di MI Walisongo antara lain adalah masa kerja. Bagi pegawai yang masa kerjanya relatif lama itu yang menjadi prioritas, dengan pertimbangan masa kerja yang cukup lama, mereka akan profesional dan menguasai terhadap bidang tugas yang diemban. Namun demikian sebelumnya harus diadakan evaluasi, jadi masa kerja yang cukup lama bukan menjadi prioritas utama, jadi tergantung pada profesionalitas dan kualitas personal

\section{f) Kompensasi.}

Kompensasi adalah balas jasa yang diberikan organisasi kepada pegawai, yang tidak dapat dinilai dengan uang dan mempunyai kecenderungan diberikan secara tetap. Pemberian kompensasi, selain dalam bentuk gaji, dapat berupa tunjangan fasilitas perumahan, kendaraan dan lain-lain. Masalah kompensasi merupakan salah satu bentuk tantangan yang harus dihadapi manajemen. Dikatakan tantangan karena imbalan yang diterima oleh para pekerja tidak lagi dipandang sebagai semata-mata sebagai alat pemuas kebutuhan materialnya. Akan tetapi sudah dikaitkan dengan harkat, martabat manusia

\section{g) Penilaian Hasil Kerja.}

Untuk melaksanakan fungsi-fungsi yang dikemukakan terdahulu, diperlukan sistem penilaian pegawai secara obyektif dan akurat. 
Penilaian tenaga kependidikan ini difokuskan pada prestasi individu dan peran sertanya dalam kegiatan sekolah. Penilaian ini bukan hanya berguna bagi sekolah, akan tetapi juga bagi pegawai tersebut. Bagi para pegawai, penilaian itu berguna sebagai umpan balik berbagai hal, seperti kemampuan, keletiha, kekurangan, dan potensi yang pada gilirannya akan bermanfaat untuk menentukan tujuan, jalur, rencana, dan pengembangan karier.

\section{Peranan Manajemen Personalia Dalam Meningkatkan Mutu Pendidikan di MI Walisongo Kabupaten Blitar}

Peningkatan kualitas pendidikan bukanlah tugas yang ringan karena tidak hanya berkaitan dengan permasalahan teknis akan tetapi mencakup berbagai persoalan yang sangat rumit dan kompleks, baik yang mencakup perencanaan, pendanaan, efesiensi dan efektifitas penyelenggaraan sekolah. Manajemen pendidikan merupakan alternatif strategis untuk meningkatkan kualitas pendidikan.

Manajemen sekolah secara langsung akan memepengaruhi dan menentukan efektif tidaknya kurikulum, berbagai peralatan belajar, waktu mengajar, dan proses pembelajaran. Dengan demikian, upaya penigkatan kualitas pendidikan harus dimulai dengan pembenahan manajemen sekolah, disamping peningkatan kualitas guru dan pengembangan sumber belajar.

Mutu pendidikan di MI Walisongo ini juga dapat dilihat dari proses pendidikan, jika dilihat dari nilai kelulusan yang seratus persen ini maka dapat dikatakan proses pendidikan yang ada dapat berjalan dengan maksimal.

Output pendidikan merupakan hasil kinerja madrasah. Hasil kinerja madrasah adalah prestasi madrasah yang dihasilkan dari proses atau perilaku madrasah. Kinerja madrasah dapat diukur dari kualitas, efektifitas, produktifitas, efisiensi, inovasi, kualitas kehidupan kerja, dan moral kerja.

\section{Faktor Penghambat Dan Pendukung Manajemen Personalia Dalam Meningkatkan Mutu Pendidikan Di MTs N Selorejo Kabupaten Blitar}

\section{a. Faktor Penghambat}

1) Dana yang minim dengan kondisi sosial ekonomi peserta didik yang rendah sehingga pihak madrasah tidak bisa membebankan biaya pendidikan yang besar kepada siswa. 
2) Rata-rata siswa yang masuk ke MI Walisongo adalah siswa sekolah dasar yang belum memiliki pengetahuan agama yang baik sehingga dibutuhkan pembelajaran yang baik untuk memenuhi tujuan pendidikan yang ditetapkan.

3) Keterbatasan tenaga pengajar sehingga ada beberapa guru yang bekerja ganda untuk memenuhi kebutuhan kurikulum.

4) Tempat tinggal personil sekolah yang letaknya jauh dari lokasi madrasah.

Akan tetapi beberapa faktor penghambat tersebut dapat diatasi dengan disiplin yang tinggi yang diterapkan oleh kepala sekolah didukung oleh loyalitas dan profesionalitas para personal itu sendiri sehingga menjadikan MI ini tidak kalah bersaing dengan MI lain di kabupaten Blitar

\section{b. Faktor Pendukung}

1) Team-work yang kompak dan transparan

2) Loyalitas personil pada madrasah yaitu bagaimana seseorang mempunyai rasa memiliki pada madrasah ini

3) Komunikasi antar personal yaitu hubungan antara atasan dengan bawahannya yang didasarkan atas rasa kekeluargaan yang persaudaraan yang tinggi.

4) Komitmen bersama, sesuai dengan yang ditekankan oleh kepala sekolah bahwa setiap personal harus memberikan yang terbaik dan pengabdian yang penuh untuk madrasah.

Keempat faktor pendukung diatas merupakan wahana untuk meningkatkan mutu pendidikan yang ada di MI Walisongo. Dengan keempat pendukung tersebut hambatan yang ada walaupun dengan kondisi dan dana yang terbatas madrasah ini mampu bertahan dan bersaing dengan madrasah lain di Kabupaten Blitar.

\section{SIMPULAN}

Pelaksanaan manajemen tenaga kependidikan (manajemen personalia) di MI Walisongo kabupaten Blitar meliputi enam kegiatan pokok, yaitu perencanaan pegawai, pengadaan pegawai, pembinaan dan pengembangan pegawai, promosi mutasi, kompensasi, dan penilaian hasil kerja pegawai.

Peranan manajemen personalia dalam meningkatkan mutu pendidikan di MI Walisongo ini ditandai dengan loyalitas, kekompakan dan koordinasi antara 
personal sekolah yaitu tenaga administratif (staff atau karyawan) dan tenaga edukatif (guru) yang matang mulai dari perencanaan sampai penilaian pegawai.

Faktor penghambat yang ada di Ml Walisongo ini adalah dana yang minim dengan kondisi sosial ekonomi peserta didik yang rendah sehingga pihak madrasah tidak bisa terlalu membebankan biaya pendidikan yang besar kepada siswa. Faktor penghambat yang lainnya adalah keterbatasan tenaga pengajar sehingga ada beberapa guru yang bekerja ganda untuk memenuhi kebutuhan kurikulum. Akan tetapi beberapa faktor penghambat tersebut dapat diatasi dengan disiplin yang tinggi yang diterapkan oleh kepala sekolah didukung oleh loyalitas dan profesionalitas para personal itu sendiri sehingga menjadikan MI ini tidak kalah bersaing dengan Ml lain di kabupaten Blitar.

\section{DAFTAR RUJUKAN}

Arcaro, S Jerome, 2005. Pendidikan Berbasis Mutu: Prinsip-Prinsip dan Tata Langkah Penerapan. Yogyakarta : Pustaka Pelajar.

Arikunto, Suharsimi, 2002. Prosedur Penelitian : Suatu Pendekatan Praktek. Jakarta. Rineka Cipta.

Artikel Pendidikan, Konsep Dasar Manajemen Peningkatan Mutu Berbasis Madrasah (MPMBM), http: www.dikdasmen.depdiknas.go.id(Diakses tanggal 20 april 2007).

Departemen Agama RI. 2005. Desain Pengembangan Madrasah. Jakarta : Direktorat jendral

Moleong, J Lexy, 2004. Metode Penelitian Kualitatif. Bandung: Remaja

M Nasir, 1988. Metode Penelitian. Jakarta: Ghalia Indonesia.

Mulyasa, E, 2003. Manajemen Berbasis Sekolah. Bandung: Remaja Rosdakarya

Mulyasa, E, 2000. Menjadi Kepala Sekolah Profesional. Bandung: Remaja Rosdakarya

Pidarta, Made. 1988. Manajemen Pendidikan Indonesia. Jakarta: Bina Aksara.

Soetopo Hendiyat dan Soemanto, Wasti. 1985. Pengantar Operasional Administrasi Pendidikan. Surabaya : Usaha Nasional.

Subroto, Suryo. Dimensi-dimensi Administrasi Pendidikan di Sekolah. Surabaya : 
Muhammad Iqbal Baihaqi. 2018. Peranan Manajemen Personalia Dalam Meningkatkan Mutu Pendididikan Di Mi Walisongo Selorejo Blitar.

Konstruktivisme, 10 (1): 49-62

Usaha Nasional.

Suderajat, Hari, Manajemen Peningkatan Mutu Berbasis Sekolah. Bandung, : CV Cekas Grafika.

Suryadi, Ace, 1992. Indikator Mutu dan EfisiensiPendidikan Sekolah Dasar di Indonesia. Jakarta: Balitbang Depdikbud

Tilaar, Suryadi, Manajemen Pendidikan Nasional. Jakarta: Rineka Cipta.

Umaedi. 2000. Manajemen Peningkatan Mutu Pendidikan. Malang: Jurnal Administrasi Pendidikan FKIP 